\title{
Determining the Rooting Ability of Hardwood Cuttings of Blueberry (Vaccinium corymbosum L.) cv. 'Bluecrop' Stored in Refrigerating Conditions
}

\author{
Sabri Braha (Corresponding Author) \\ University of Prishtina, Faculty of Agriculture and Veterinary, Str."Bill Clinton" n.n.10000 \\ Prishtina, Kosova \\ Email: sabribraha@yahoo.com \\ Petrit Rama \\ Department of Horticulture and Landscape Architecture, Agricultural University of \\ Tirana,Tirana Albania \\ Email: ramapetrit@yahoo.gr
}

Agim Zajmi

University of Prishtina, Faculty of Agriculture and Veterinary, Str."Bill Clinton” n.n.10000 Prishtina, Kosova

Email: zajmi@hotmail.com

Received: Dec. 16, 2019 Accepted: Jan. 12, 2020 Published: Jan. 21, 2020

doi:10.5296/jas.v8i3.16309 URL: https://doi.org/10.5296/jas.v8i3.16309

\begin{abstract}
This experiment has been carried out in order to determine the rooting ability of hardwood cuttings of the blueberry cultivar 'Bluecrop' collected during the deep dormant winter period in the last part of January. In order to induce the adventitious roots formation, the cuttings were stimulated using Indol Butyric Acid (IBA) and Naphthalene Acetic Acid (NAA) in various concentrations (1500, 3000, $4500 \mathrm{ppm})$, whilst one row in each box remained intact (control). The collection of cuttings off the mother plant at the beginning of January enable the nutrients and other matter that help the process of rooting not to move from the base of cutting towards the top and consequently they remain at the base of cutting which results with
\end{abstract}


quite a high rooting percentage (up to $72.5 \%$ ) compared to the cuttings collected in February with rooting percentage of $67.5 \%$ and in March (52\%). In both types of substrate, turf and turf-perlite 2:1 and in different time periods when cuttings have been collected, IBA proved to be better in inducing adventitious roots compared to NAA.

Keywords: hard wood cuttings, IBA, NAA, rooting, substrate, turf-perlite

\section{Introduction}

The highbush blueberry is a fresh climate plant which is successfully cultivated at altitudes ranging from 300 to $800 \mathrm{~m}$ whilst in southern localities up to $1000 \mathrm{~m}$ altitude. The highbush blueberry requires acid soils at the $\mathrm{pH}$ range $=4.0-5.5$ with a high amount of organic matter, $\mathrm{Fe}$ and $\mathrm{N}$ in the form of $\mathrm{NH}_{4}^{+}$(Darnell \& Hiss, 2006). Likewise, the soil should be well drained and sufficiently aerated, and with a relatively sustainable amount of moisture. Both, the temperature and the presence of oxygen affect the pace of ammoniacal nitrogen from the blueberry's root system, knowing that the metabolism of ammoniacal nitrogen demands much more oxygen than the metabolism of nitrate nitrogen. At the same time, the oxygen solubility in water reduces in low temperatures and the root system has small amounts of oxygen, therefore under these conditions the assimilation of ammoniacal nitrogen by the blueberry plant is reduced significantly. On the other hand, low temperatures influence the major amount of carbohydrates that head towards the root system, likewise the amount of oxygen dissolved in water becomes higher and as a result the absorption of ammoniacal nitrogen by the blueberry plant is significantly increased. Furthermore, the absorption of iron by the blueberry root system is easier under $\mathrm{pH} 4.3$. On the contrary iron absorption under $\mathrm{pH}>5$ becomes more difficult (Peterson et al., 1988). Therefore, the relation between ammoniacal nitrogen $\left(\mathrm{NH}_{4}{ }^{+}\right)$ and nitrate nitrogen $\left(\mathrm{NO}_{3}{ }^{-}\right)$is very important and does have influence on the blueberry development. This relation also varies depending on the growth stage of the plant as well as the $\mathrm{pH}$ at the root area and the physical and chemical properties of the soil. For this reason blueberry cultivation requires well aerated soils. When temperatures are high the respiration of plants increases parallel with the consumption of sugars, thus reducing the available amount of sugars transported towards the roots that participate in the metabolism of ammoniacal nitrogen (Ballinger et al., 1982). V. corymbosum has a root system which is susceptible to drought (Lyrene, 1997). Subsequent to a numerous special requirements that this plant has, the production increase is limited if there is no way to overcome some of these specific factors conditional for the production of blueberry in larger areas. The use of hardwood cuttings is easier and at the same time is the most common method of vegetative propagation (Anderson $\&$ Woods, 1999). There are several successful methods of blueberry production in a vegetative way that could potentially be used to propagate blueberry $V$. corymbosum L. This is achieved using well-lignified hardwood cuttings, semi-lignified cuttings and soft-wood cuttings. These are the most used methods for the propagation of blueberries during which the rooting percentage reaches over 50\% (Mainland, 1993). The rooting success of cuttings depends on the species and the cultivar, the condition of hardwood cuttings, the type of hardwood cuttings, the season and many other factors (Hartmann et al., 2002). The rooting ability is a feature which changes during the different stages of plant development. Application of auxin, especially indol butyric acid (IBA) is one of the most common and 
effective means to increase the culture rooting. IBA is more effective in the promotion of adventitious roots in stem cuttings (Waisel et al., 1991). The initiation of adventitious roots and their growth is an intensive metabolic process promoted by auxins and other growth regulators, leading to the increase of enzymatic activities for the synthesis of ARN and proteins (Legue et al., 2014). Auxin is widely used in hardwood cuttings to accelerate and form adventitious roots (Galavi et al., 2013). The rooting capacity for stem cuttings is determined by the interaction of stem cell inheritance factors, the level of auxin in leaves and buds of cuttings, the reserved amount of carbohydrates in cuttings, the plant growth stage and the location of the cutting in the offshoot (Rosier et al., 2006). The level of auxins in the cell impacts the regulation of genes expression which determines the fate of cells, the asymmetric separation of which is an important impact for root formation (Galinha et al., 2007). In many species, the application of exogenous auxins is needed to achieve the rooting (Diaz et al., 1996). The root system of highbush blueberry is superficial and mainly found in a depth of 10-15 cm, comprised of many thin threads, without fibril roots, but they have mycorrhiza (coexistence with fungus) which lives in symbiosis with the root, also playing the role of fibril roots. Endotrophic mycorrhizae increases the absorption power of blueberry roots. Their presence plays an important role in the feeding of blueberries. The greatest benefit from symbiosis with fungus is to increase the inputs for nitrogen (access to different sources of ammoniacal nitrogen), absorbing mineral ions which are hard to move from the soil (phosphorous, iron), and in the case of excessive ions and piled up in their cells. In this way it stops their transportation and toxic impact in the plant. The most part of the root system of the blueberry Vaccinium angustifolium, Vaccinium myrtilloides is adventitious.

\section{Material and Methods}

The experiment has been carried out during the vegetation period of 2017 in Llukë e Epërme village (Peja region). The experiment follows the method (Zec et al., 2001). The propagation material used were one-year-old well-lignified offshoots 6 to $12 \mathrm{~mm}$ thick without fruit buds at the end of January at the time of deep winter dormant period before bud swelling. Offshoots taken during January are cut at $15 \mathrm{~cm}$ length, several mm over the higher bud and several mm under the lower bud. Such cuttings are put into polyethylene bags and hermetically closed to prevent dehydration and are stored in refrigerating conditions at a temperature between 0 and $3{ }^{\circ} \mathrm{C}$ for a certain period of time and later placed for rooting in boxes filled with substrate turf-only and turf-perlite 2:1 (substrate thickness $25 \mathrm{~cm}$ ). Prior to being placed in boxes for rooting the cut pieces are prepared, tied in tubes and their basal part is dipped in a solution IBA and NAA up to $2.5 \mathrm{~cm}$ with different concentrations of $1500 \mathrm{ppm}$, $3000 \mathrm{ppm}$ and $4500 \mathrm{ppm}$, in a duration of 5-7 seconds, whilst one row in each box was not treated at all (control). At the bottom of boxes for rooting, a layer of gravel is placed to ensure the drainage of excessive water. Such treated cuttings were kept for 15 minutes (until they absorbed well IBA and NAA), and afterwards were powdered in their base with captan powder mixed with talk (at a ratio 1:10 - against rooting), than they were placed in boxes for rooting at a distance $10 \times 5 \mathrm{~cm}$, in a depth of around $1 / 2$ of the cutting length leaving at least two buds over the substrate where they were kept for eight weeks. The experiment was placed in four boxes with four repetitions each, one repetition $=40$ cuttings $40 \times 4=160$ 
cuttings/box. The rooting of cuttings took place by heating the base (through pipes circulating warm water) managing to keep a certain temperature at the base part of cuttings exactly where the roots come out. The temperature was $21 \mathrm{c}^{\circ}$ during the day (whilst $15-16 \mathrm{c}^{\circ}$ during the night), and the air temperature in the rooting environment was for $4 \mathrm{c}^{\circ}$ lower in order to create a difference between the base of the cutting and the top of the cutting, in this way temporarily preventing the development of buds found in the terminal part of the cutting whilst the reserves of carbohydrates were oriented towards the base of the cutting which resulted with the formation of adventitious roots. The boxes filled with substrate for rooting of the hardwood cuttings were placed in a glasshouse with relative air moisture between $75-80 \%$.

\section{Results and Discussion}

The three ways analysis of variance (ANOVA) on the percentage of rooting for hardwood cuttings taken at the beginning of January (Table 2) shows that there are statistically verified changes at the level of authenticity $\mathrm{p}=0.01$ between the variants with stimulation compared to the control. Concentration effects of growth bioregulators IBA and NAA from 3000 ppm were important compared to the control. The rooting percentage of hardwood cuttings in the substrate turf-perlite 2:1, collected at the beginning of January reached up to $72.5 \%$ in the variant IBA $3000 \mathrm{ppm}$ compared to the cuttings placed in the substrate turf-only where the rooting percentage was $57.5 \%$ in the same variant IBA $3000 \mathrm{ppm}$. However, for hardwood cuttings taken one month later in the middle of February (substrate turf-perlite 2:1) the rooting percentage was $67.5 \%$ whilst in the substrate turf-only it was $55 \%$ also stimulated with IBA $3000 \mathrm{ppm}$. For hardwood cuttings taken in the middle of March the rooting percentage resulted $52.5 \%$ on IBA $3000 \mathrm{ppm}$ in the same substrate turf-perlite 2:1, whilst in substrate turf-only the rooting percentage reached $40 \%$. This difference in the percentage of hardwood cuttings is related to the interaction with the timeline, hormonal equilibrium and the effect of IBA and NAA. Indol butyric acid (IBA) in all concentrations proved to be more efficient in inducing adventitious roots on hardwood cuttings compared to Naphthalene acetic acid (NAA). Regarding the concentration, the variant $3000 \mathrm{ppm}$ was proven more favorable in the rooting of hardwood cuttings having in mind that the concentrations of auxin over 3000 ppm may prevent the germination of buds of the cutting and contribute to the rotting of the base part of the cutting. The rooting percentage of hardwood cuttings in this research is in line with the results of other authors (Zec et al., 2001) who have implemented the rooting of blueberry hardwood cuttings in the 'Bluecrop' cultivar. 
Table 1. Average data on the percentage of rooting of hardwood cuttings taken in January

\begin{tabular}{|c|c|c|c|c|c|c|c|}
\hline \multirow[b]{2}{*}{$\begin{array}{l}\text { Factor - A } \\
\text { Substrate }\end{array}$} & \multicolumn{7}{|c|}{ Repetition } \\
\hline & $\begin{array}{l}\text { Facto r- B } \\
\text { Growths } \\
\text { regulators }\end{array}$ & $\begin{array}{l}\text { Factor - C } \\
\text { Concentrati } \\
\text { on }\end{array}$ & $\mathrm{R} 1$ & R2 & R3 & $\mathrm{R} 4$ & Average \\
\hline \multirow{8}{*}{ Turf } & \multirow{4}{*}{ IBA } & control & 2.0 & 1.0 & 2.0 & 1.0 & 1.50 \\
\hline & & $1500 \mathrm{ppm}$ & 4.0 & 5.0 & 3.0 & 4.0 & 4.00 \\
\hline & & $3000 \mathrm{ppm}$ & 7.0 & 5.0 & 6.0 & 6.0 & 6.00 \\
\hline & & $4500 \mathrm{ppm}$ & 4.0 & 5.0 & 5.0 & 4.0 & 4.50 \\
\hline & \multirow{4}{*}{ NAA } & control & 1.0 & 2.0 & 1.0 & 1.0 & 1.25 \\
\hline & & $1500 \mathrm{ppm}$ & 3.0 & 3.0 & 4.0 & 3.0 & 3.25 \\
\hline & & $3000 \mathrm{ppm}$ & 6.0 & 4.0 & 5.0 & 5.0 & 5.00 \\
\hline & & $4500 \mathrm{ppm}$ & 3.0 & 4.0 & 4.0 & 5.0 & 4.00 \\
\hline \multirow{8}{*}{$\begin{array}{l}\text { Turf-Perlit } \\
\text { e }\end{array}$} & \multirow{4}{*}{ IBA } & control & 2.0 & 1.0 & 2.0 & 2.0 & 1.75 \\
\hline & & $1500 \mathrm{ppm}$ & 4.0 & 5.0 & 4.0 & 6.0 & 4.75 \\
\hline & & $3000 \mathrm{ppm}$ & 7.0 & 7.0 & 8.0 & 7.0 & 7.25 \\
\hline & & $4500 \mathrm{ppm}$ & 6.0 & 5.0 & 6.0 & 4.0 & 5.25 \\
\hline & \multirow{4}{*}{ NAA } & control & 1.0 & 2.0 & 1.0 & 2.0 & 1.50 \\
\hline & & $1500 \mathrm{ppm}$ & 3.0 & 4.0 & 5.0 & 3.0 & 3.75 \\
\hline & & $3000 \mathrm{ppm}$ & 7.0 & 6.0 & 4.0 & 6.0 & 5.75 \\
\hline & & $4500 \mathrm{ppm}$ & 4.0 & 5.0 & 6.0 & 4.0 & 4.75 \\
\hline
\end{tabular}

Table 2. The three way analysis of variance (ANOVA) on the percentage of rooting for hardwood cuttings taken in January

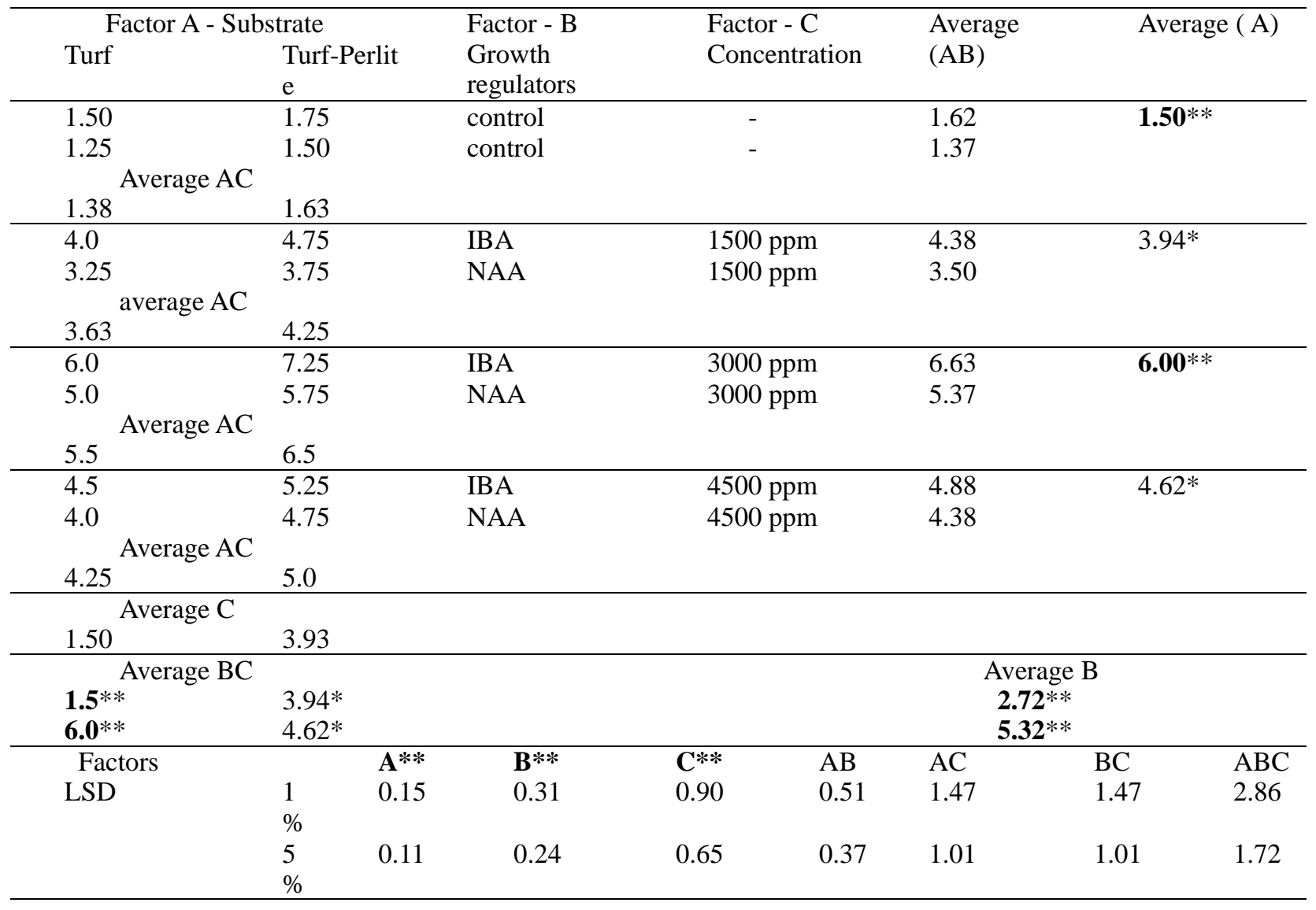

The three way ANOVA according to the test by Vukadinovic** significant $0.01 \%$ level. 


\section{Al Macrothink}

Numbers in bold show the most important attribute for variant.

The rooting percentage of hardwood cuttings (initiation of adventitious roots) is in full dependency since cuttings are taken (figure 1). In this context, the correlation coefficient ( $\mathrm{r}$ $=0.9231)$ is closer to \pm 1 and is interpreted as a coefficient with close correlation, thus, there is a very close connection between the time when cuttings have been collected and the percentage of rooting which shows that our research is in accordance with other authors regarding the rooting ability of hardwood cuttings in different stages of plant development (Rama P. 2013).

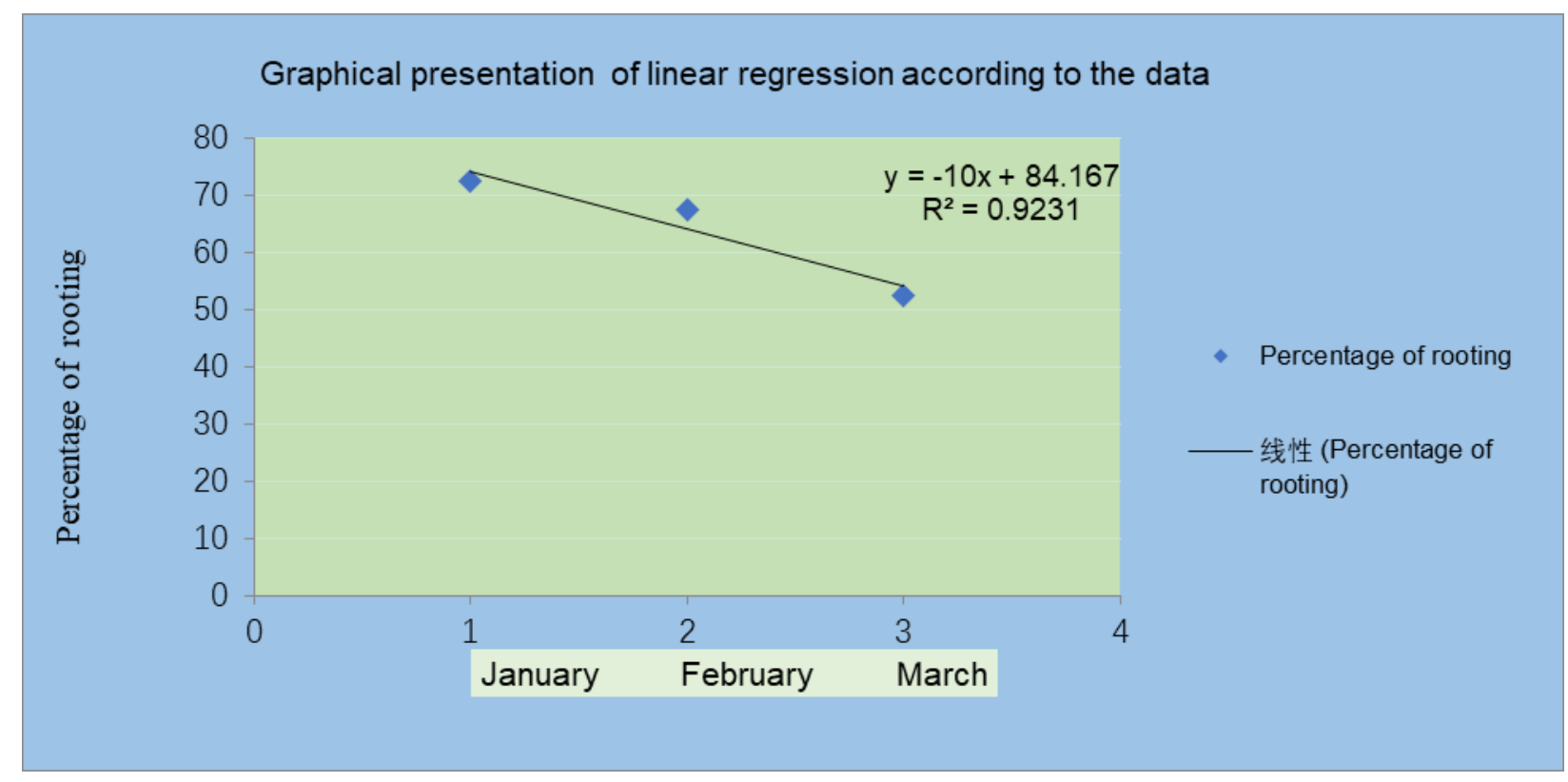

Figure 1. Linear function $\left(\mathrm{y}_{\mathrm{t}}=\mathrm{a}+\mathrm{bx}\right)$ which shows the dependency of the hardwood cuttings' rooting percentage, 'Bluecrop' cultivar in relation to the time when the cuttings were collected.

IBA was proven more effective in all concentrations and in the two types of rooting substrate, in inducing adventitious roots in hardwood cuttings compared to NAA. This is in line with the results of (League et al. 2014), and (Galavi et al. 2013). 


\section{Macrothink}

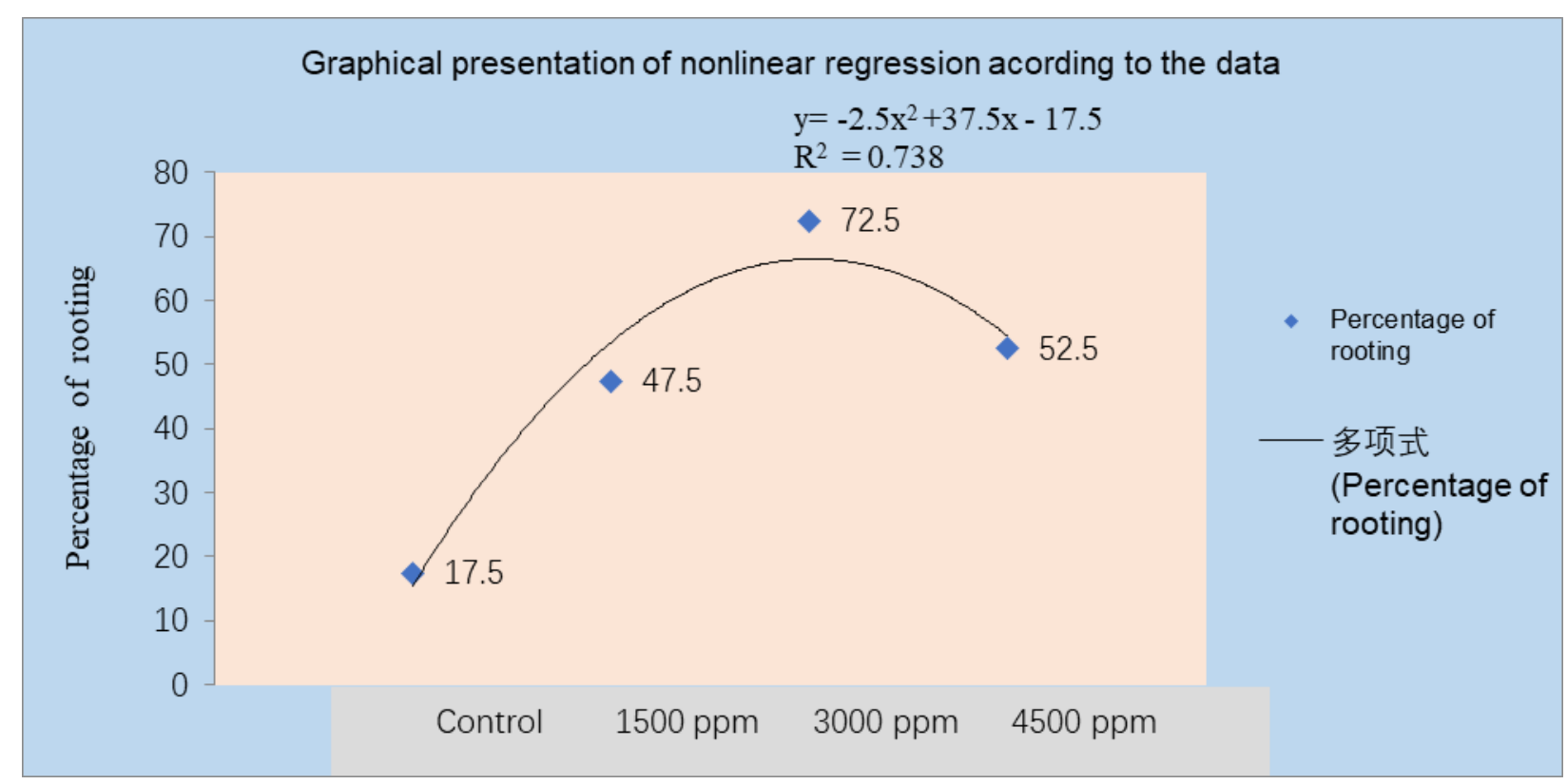

Figure 2. Nonlinear function $\left(\mathrm{yt}_{\mathrm{t}}=\mathrm{a}+\mathrm{bx}+\mathrm{cx}^{2}\right)$ expressing the dependency of percentage of rooting of hardwood cuttings, Bluecrop cultivar in relation to different concentrations of IBA

Figure 2. shows that with the increase of IBA and NAA concentrations from 1500 to 3000 ppm the rooting percentage also increases, followed by a decline of concentrations over 3000 ppm. In this context the value of coefficient $r=0.738$ shows that there is a close link between the concentration of growth bioregulators (IBA and NAA) and the percentage of rooting. In all concentrations as well as in both types of the substrate IBA $3000 \mathrm{ppm}$ resulted with a higher percentage in the rooting of hardwood cuttings. The promotion effect of IBA in rooting is mainly a result of its conversion to IAA in plant tissues. However, IAA which is needed for the process of rooting, is easily oxidized from peroxidases, whilst IAA released from IBA does not oxidize from peroxidases and remains in the base of the cutting (Zahra et al., 2012). The highest values of rooting percentage are definitely related to the time when cuttings were collected, the type of growth bioregulators and the type of substrate.

\section{Conclusion}

The time of collecting the cuttings is crucial for the rooting success, since at different time periods the presence of different hormonal substances and the matter that favours the rooting of hardwood and vegetative cuttings in cv. 'Bluecrop' changes.

The turf-perlite substrate 2:1 has shown to be more favourable during the rooting of hardwood cuttings, compared to the turf-only substrate, since the presence of perlite helps the aeration of the substrate, knowing that all processes that lead to the formation of adventives roots are aerobe processes - oxygen presence is necessary. IBA has shown to be more effective in all concentrations and in both types of substrate in inducing adventives roots in hardwood cuttings of the stem cv 'Bluecrop' compared to NAA. 


\section{1) Macrothink}

Journal of Agricultural Studies

ISSN 2166-0379

2020, Vol. 8, No. 3

\section{References}

Anderson, R. G., \& Woods, T. A. (1999). An economic evaluation of single stem cut rose production. Acta Horticulturae, 481, 629-634. https://doi.org/10.2298/JAS1503263N

Ballinger, E., Maness, E. P., \& Ballington, J. R. (1982). Anthocianins in ripe fruit of the sparkleberry, Vaccinium arboretum MARSH. Can. J. Plant Sci., 62, 683-687. https://doi.org/10.4141/cjps82-099

Darnell, R. 1., \& Hiss, S. A. (2006). Uptake and assimilation of nitrate and iron in two Vaccinium species as effected by external nitrate concentration. J. Amer. Soc. Hort., 131, 5-10.

Diaz-Sala, C., Hutchison, K. W., Goldfarb, B., \& Greenwood, M. S. (1996). The role of auxin transport, metabolism and tissue sensitivity. Physiologia Plantarum, 97(3), 481-490. https://doi.org/10.1034/j.1399-3054.1996.970310.x

Galavi, M., Karimian, M. A., \& Mousavi, S. R. (2013). Effects of Different Auxin (IBA) Concentration and Planting - Beds on Rooting Grape Cuttings. Annual Review \& Research in Biology, 3(4), 517-523.

Galinha, C., Hofhuis, H., Luijten, M., Willemsen, V., Blilou, I., Heidstra, R., \& Scheres, B. (2007). Plethora Proteins and dose - dependent master regulators of Arabidiopsis root development. Nature, 449, 1053-1057. https://doi.org/10.1038/nature06206

Hartmann H. T., Kester, D. E., Davies, F. T., \& Geneve, R. L. (2002). Plant propagation, Principles and Practices, 7th ed., Prentice Hall, New Jersey, pp. 646, 880. https://aggie-horticulture.tamu.edu

Legue, V., Rigal, A., \& Bhalerao, R. P. (2014). Adventitious root formation in tree species: involvement of transcription factors. Phys. Plant, 151, 192-198. https://doi.org/10.1111/ppl.12197

Lyrene, P. M. (1997). Value of various taxa in breeding tetraploid blueberries in Florida. Euphytica, 94, 15-22. https://doi.org/10.1023/A:1002903609446

Mainland, C. M. (1993). Effects of media, growth stage and removal of lower leaves on rooting of highbush, southern highbush and rabbiteye softwood or hardwood cuttings. Acta Hort., 346, 133-140. https://doi.org/10.17660/ActaHortic.1993.346.18

Rama P. (2013). Multiplication of horticultural plants. Agricultural University of Tirana. Tiranë.

Peterson, L. A., Stang, E. J., \& Dana, M. N. (1988). Blueberry response to $\mathrm{NH}_{4}-\mathrm{N}$ and $\mathrm{NO}_{3}$ -N. Journal of the American Society for Horticultural Science, 112, 612-616.

Rosier, C. L., Frampton, J., Goldfarb, B., \& Blazich, F. C. (2006). Improving the Rooting Capacity of Stem Cuttings of Virginia Pine by severe Stumping of Parent Trees. Southern Journal of Applied Forestry, 30(4), 172-181. https://doi.org/10.21275/v5i7.ART2016324 
Waisel, Y., Ashel, A., \& Kafkafi, U. (1991). Plant roots: the hidden half. New York; March dekker, inc. https://doi.org/10.2298/JAS1503263N

Zahra, T. R., \& Hsan, H. S. (2012). Effect of different auxin concentration on Virginia creeper (Parthenoccissus quinquefolia) rooting. Applied Sciences Journal, 16, 7-10. https://doi.org/10.2298/JAS1503263N

Zec, G., Colić, S., Todorović, R., \& Marinković, D. (2001): Ožiljavanje visokožbunaste borovnice (Vaccinium corymbosum L.) zrelim reznicama, Jugoslovensko voćarstvo, Ċaćak, $35,117-123$.

\section{Copyright Disclaimer}

Copyright for this article is retained by the author(s), with first publication rights granted to the journal.

This is an open-access article distributed under the terms and conditions of the Creative Commons Attribution license (http://creativecommons.org/licenses/by/4.0/). 